AJIE - Asian Journal of Innovation and Entrepreneurship

(e-ISSN: 2477- 0574; p-ISSN: 2477-3824)

Vol. 01, No. 01, January 2016

\title{
IMPLEMENTASI PROGRAM DANA BANTUAN \\ PEMBERDAYAAN USAHA GARAM RAKYAT (PUGAR) DALAM \\ RANGKA PENGEMBANGAN WIRAUSAHA GARAM RAKYAT \\ (Studi Pada Dinas Kelautan Dan Perikanan Kabupaten Sumenep)
}

\author{
Bagus Ananda Kurniawan \\ Program Studi Ilmu Administrasi Negara, Universitas Bhayangkara, Kota Surabaya, Jawa Timur, \\ Indonesia \\ Email: bagusanandakurniawan@gmail.com
}

\begin{abstract}
This qualitative research method to describe and analyze a policy which aims to empower the people in the salt business Sumenep portrayed through the study of Program Implementation Assistance Fund for Empowerment of People's Salt (PUGAR) with an emphasis on policy implementation model consisting Grindle of contents (contents of policy) and (contexts of policy) policy implementation. Empowerment of People's Salt (PUGAR) sourced from the state budget is a development program that focused on improving the welfare of the farmers of salt, as well as increased production and product quality salt. The research findings indicate that Content Policy (Of Content Policy) covers Salt Empowerment of People (PUGAR) has been established through the minister of marine and fisheries regulation number 41 of 2011 on guidelines for the implementation of the National Program for Community Empowerment and Fisheries. implementation of the policy (the Context of Policy) includes a companion team PUGAR Department of Marine and Fisheries Sumenep identifying the existence and location of the land to the group PUGAR group that has submitted a proposal for assistance and workshops as well as socialization PUGAR annually. The conclusion of the study include the provision of information about program implementation PUGAR up the thawing process is less clear PUGAR assistance received by a group of farmers salt (KUGAR). Salt farmer business groups of people (KUGAR) Recipient PUGAR each year hoping PUGAR funds disbursed prior to the production of salt, this PUGAR funds transferred to a bank account belonging to a business group of salt farmers (KUGAR) and use this PUGAR funds must be adapted to the Joint Venture Plan (RUB ) contained in the Accountability Report (LPJ) proposals submitted for the salt farmers PUGAR each group of people (KUGAR).
\end{abstract}

Keywords: Empowerment of People's Salt (PUGAR), Entrepreneurial Salt People

\begin{abstract}
ABSTRAK
Penelitian dengan metode kualitatif ini untuk mendeskripsikan dan menganalisis sebuah kebijakan yang tujuannya untuk memberdayakan usaha garam rakyat di Kabupaten Sumenep yang dipotret melalui kajian Implementasi Program Dana Bantuan Pemberdayaan Usaha Garam Rakyat (PUGAR) dengan penekanan pada model implementasi Kebijakan Grindle yang terdiri dari isi (contents of Policy) dan (contexts of policy) pelaksanaan kebijakan. Pemberdayaan Usaha Garam Rakyat (PUGAR) yang bersumber dari APBN merupakan program pemberdayaan yang difokuskan pada peningkatan kesejahteraan bagi petambak garam, serta peningkatan produksi dan kualitas produk garam. Temuan penelitian menunjukkan bahwa Isi Kebijakan (Content Of Policy) meliputi Pemberdayaan Usaha Garam Rakyat (PUGAR) ini telah ditetapkan melalui peraturan menteri kelautan dan perikanan nomor 41 tahun 2011 tentang pedoman pelaksanaan Program Nasional Pemberdayaan Masyarakat Mandiri Kelautan dan Perikanan. pelaksanaan kebijakan (Context of Policy) meliputi tim pendamping PUGAR Dinas Kelautan dan Perikanan Kabupaten
\end{abstract}


Sumenep melakukan identifikasi keberadaan kelompok dan lokasi lahan kepada kelompok PUGAR yang telah mengajukan proposal permohonan bantuan PUGAR dan lokakarya maupun sosialisasi setiap tahunnya. Kesimpulan penelitian ini meliputi pemberian informasi tentang pelaksanaan program PUGAR hingga proses pencairan bantuan PUGAR kurang jelas diterima oleh kelompok usaha petani garam (KUGAR). Kelompok usaha petani garam rakyat (KUGAR) Penerima PUGAR setiap tahunnya berharap dana PUGAR dicairkan sebelum masa Produksi Garam, dana bantuan PUGAR ini ditransfer ke rekening bank milik kelompok usaha petani garam (KUGAR) dan penggunaan dana PUGAR ini harus disesuaikan dengan Rencana Usaha Bersama (RUB) yang terdapat dalam Laporan Pertanggung Jawaban (LPJ) proposal pengajuan dana PUGAR setiap kelompok petani garam rakyat (KUGAR).

Kata Kunci: Pemberdayaan Usaha Garam Rakyat (PUGAR), Wirausaha Garam Rakyat

\section{PENDAHULUAN}

Menurut Peraturan Menteri (PERMEN) Kelautan dan Perikanan Republik Indonesia nomor PER.07/MEN/2012 tentang Pedoman Teknis Pemberdayaan Usaha Garam Rakyat (PUGAR) tahun 2012. Sebagai rencana awal Peluncuran dari Program PUGAR Tahun 2011, Kementerian Kelautan Perikanan (KKP) menetapkan 40 Kabupaten.Kota dan 9 (sembilan) Propinsi dengan luas lahan garam rakyat seluas $33.854,36$ ha dan lahan produksi garam tahun 2011 seluas 24.130,92 hektar dengan anggaran Rp. 72 Miliyar. Pada tahun 2011 PUGAR telah mampu memberdayakan 1.728 kelompok usaha garam rakyat yang terdiri dari 16.399 petambak garam rakyat di 241 desa pada 90 kecamatan.

Permasalahan program pemberdayaan usaha garam rakyat (PUGAR) di Kabupaten Sumenep. Penyelewengan dana bantuan PUGAR ini meliputi anggota kelompok KUGAR yang mengajukan dana bantuan PUGAR ke Dinas Kelautan dan Perikanan Kab.Sumenep untuk mendapatkan bantuan dana PUGAR tidak bekerja sebagai petani garam dan juga tidak mempunyai lahan garam maupun tidak menyertakan bukti sewa lahan garam dari pihak PT.GARAM yang menyewakan lahan garamnya ke petani garam rakyat dan di curigai karena memiliki unsur kedekatan kepada Perangkat Desa atau Kepala Desa setempat atau masih keluarga sendiri sehingga sangat mudah mendapatkan dana PUGAR tersebut. Diutamakan pada Tahun 2013 maupun tahun 2014 yang mendapatkan dana PUGAR adalah kelompok baru dan kelompok yang sudah terbentuk tahun 2011, tahun 2012 dan tahun 2013

Besaran dana bantuan yang diterima petani garam juga beragam nominalnya. Sebelum dana PUGAR ini dicairkan harus melalui beberapa tahap. Tahap awal proses verifikasi Kelompok Usaha Garam Rakyat (KUGAR) Identifikasi dan seleksi terhadap proposal yang masuk ke Dinas Kelautan dan Perkanan Kabupaten Sumenep pertama kali dilakukan oleh Tenaga Pendamping, baik secara administrasi maupun pengecekan kelapangan, sekaligus verifikasi langsung kepada kelompok pengusul. pendamping melakukan identifikasi dan seleksi awal kepada kelompok PUGAR yang telah mengajukan proposal permohonan bantuan PUGAR tahun 2013.

Selanjutnya menghubungi anggotanya sekaligus mengecek keberadaan kelompok, loksai lahan, luas lahan serta mencocokkan kebenarannya. Apabila proposal yang diajukan kelompok belum sesuai dengan Petunjuk Teknis PUGAR 2013, maka pendamping memberitahukan kepada kelompok yang bersangkutan agar proposalnya dilengkapi, setelah lengkap dan sudah sesuai dengan juknis. Tahap kedua adalah Hasil verifikasi Kelompok KUGAR yang 
dilakukan Tenaga Pendamping Dinas Kelautan dan Perikanan Kab.Sumenep.

Bagi Kelompok KUGAR penerima diharuskan untuk membuka Rekening di Bank yang sudah ditunjuk oleh pemerintah sebagai penyalur dana BLM PUGAR 2013, dalam hal ini Bank BNI 46 sebagai bank penyaluran dana PUGAR Kab.Sumenep.

Penulis tertarik mengambil penelitian ini karena Kabupaten Sumenep merupakan salah satu Kabupaten di Pulau Madura, yang terkenal sebagai Pulau Garam. Bahkan Perusahaan Milik BUMN yakni PT. GARAM berada di wilayah Kabupaten Sumenep dan sekitar wilayah Pulau Madura yang lain. Lahan garam rakyat yang ada di wilayah Kabupaten Sumenep secara status kepemilikan bisa dibedakan menjadi milik masyarakat dan milik PT. GARAM tersebar dari 14 Kecamatan yakni Kota Sumenep, Pragaan, Gili Genting, Saronggi, Kalianget, Talango, Gapura, Dungkek, Ra'as, Arjasa, Sapeken dan Kangayan. Luas lahan tambak Garam di Sumenep mencapai 5.368 hektare, meliputi lahan milik PT. Garam seluas 3.300 hektar, dan lahan garam rakyat seluas 2.068 hektar. Pada tahun 2013 Target Luas Lahan melalui PUGAR yang ditetapkan seluas $1.744,38$ Ha tetapi yang tercapai seluas 1.977,2047 Ha. produktivitas rata-rata perhektar lahan garam rakyat sebesar 3050 ton.

Salah satunya Kecamatan di Kabupaten Sumenep adalah Kalianget. Kecamatan Kalianget adalah salah satu penghasil garam yang ada di Kabupaten Sumenep. Di Kecamatan Kalianget juga terdapat perusahaan BUMN yang bergerak dibidang garam yakni PT.Garam. PT Garam bertugas memasarkan garam-garam milik perusahaan maupun rakyat dan PT Garam berdiri sejak zaman belanda. Selain ada perusahaan BUMN yang bergerak di bidang garam seperti PT.Garam, terdapat pula perusahaan swasta yang bergerak dibidang garam dan menampung atau menyerap garam milik petani garam yakni PT.Garindo.

Berkaitan dengan latar belakang serta fenomena tersebut, maka permasalahan dalam penelitian ini dirumuskan sebagai berikut adalah: Bagaimanakah Implementasi Program Dana Bantuan Pemberdayaan Usaha Garam Rakyat (PUGAR) Dalam Rangka Pengembangan Wirausaha Garam Rakyat?, Bagaimanakah Kemitraan Pemangku Kebijakan dalam Mengimplementasikan Program Dana Bantuan Pemberdayaan Usaha Garam Rakyat (PUGAR) Dalam Rangka Pengembangan Wirausaha Garam Rakyat?, Bagaimanakah Faktor Pendukung dan Faktor Penghambat dari Implementasi Program Dana Bantuan Pemberdayaan Usaha Garam Rakyat (PUGAR) Dalam Rangka Pengembangan Wirausaha Garam Rakyat?

Penulis mencoba merumuskan tujuan penelitian ini berkaitan dengan permasalahan rumusan masalah diatas sebagai berikut: Untuk mendekripsikan dan menganalisis Implementasi Program Dana Bantuan Pemberdayaan Usaha Garam Rakyat (PUGAR), Keterlibatan Pemangku Kebijakan dalam ikut serta Implementasi Program Dana Bantuan Pemberdayaan Usaha Garam Rakyat (PUGAR) Faktor Pendukung dan Faktor Penghambat dari Implementasi Program Dana Bantuan Pemberdayaan Usaha Garam Rakyat (PUGAR).

\section{METODOLOGI PENELITIAN}

Berdasarkan pada permasalahan yang diangkat didalam penelitian ini maka metode penelitian yang digunakan adalah dengan pendekatan deskriptif kualitatif, yaitu suatu metode dalam meneliti status seseorang, suatu objek, suatu situasi atau kondisi sistem pemikiran.

Metode penelitian yang digunakan dalam penelitian ini adalah deskriptif dengan pendekatan kualitatif. Jenis 
Pendekatan yang dipilih peneliti adalah pendekatan deskriptif kualitatif

\section{Metode Pengumpulan Data}

Adapun objek yang diteliti dalam penelitian ini adalah Implementasi Program Dana Bantuan Pemberdayaan Usaha Garam Rakyat (PUGAR) Dalam Rangka Pengembangan Wirausaha Garam Rakyat. Petani garam di ketiga desa meliputi Desa Karang Anyar, Desa Gersik Putih dan Desa Kalianget Kab.Sumenep yang menjadi situs penelitian.

Dalam penelitian ini, yang menjadi lokasi penelitian adalah Kabupaten Sumenep dengan pertimbangan adalah Dinas Kelautan dan Perikanan Kabupaten Sumenep.

Sedangkan situs penelitian adalah tempat dimana peneliti dapat menangkap dan mengetahui keadaan sebenarnya dari objek yang diteliti guna memeroleh data yang valid dan akurat.

a) Terdapat Perusahaan milik BUMN yakni PT. Garam Persero sebagai stakeholder pendukung dalam melakukan penelitian disebabkan karena PT. Garam Persero merupakan perusahaan yang bergerak dibidang produksi garam dan menyerap membeli hasil panen garam milik rakyat di Kabupaten Sumenep.

b) Penulis mengambil tiga desa yang dianggap memiliki potensi dan petani garam Rakyat Binaan dalam meningkatkan pengelolahan Garam Rakyat di Kecamatan Kalianget Kabupaten Sumenep terdiri dari Ketiga Desa adalah Desa Karang Anyar, Desa Gersik Putih dan Desa Kalianget dan Koperasi Astagina. Serta Paguyuban Petani Garam Rakyat Kabupaten Sumenep (PERRAS) bertugas menampung aspirasi permasalahan yang dihadapi oleh petani Garam rakyat dan penyaluran dana PUGAR
HASIL DAN PEMBAHASAN

Implementasi Program Dana

Bantuan Pemberdayaan Usaha Garam Rakyat (PUGAR) Dalam Rangka Pengembangan Wirausaha Garam Rakyat

- Tahapan dan Proses Dana Bantuan Pemberdayaan Usaha Garam

Rakyat (PUGAR).

Poin pertama dari Implementasi Kebijakan Publik Grindle adalah isi kebijakan (Content of Policy) atau konten kebijakan. Pada poin ini meliputi tahap perumusan dana bantuan PUGAR berdasarkan Pemberdayaan Usaha Garam Rakyat (PUGAR) ini telah ditetapkan melalui pertauran menteri kelautan dan perikanan nomor 41 tahun 2011 tentang pedoman pelaksanaan Program Nasional Pemberdayaan Masyarakat Mandiri Kelautan dan Perikanan tahun 2011. Tim pendamping dan Tim teknis PUGAR yang dibentuk Dinas Kelautan dan Perikanan Kab,Sumenep dan dikoordinasikan dengan Kementerian Kelautan dan Perikanan RI. Tahap perumusan dana Bantuan PUGAR meliputi pembagian dan pengalokasian besaran dana Bantuan PUGAR perkelompok, pembentukan kelompok petani garam (KUGAR), verifikasi pengajuan proposal petani garam, survei lahan apakah lahan milik petani garam dan bukti sewa lahan milik PT.GARAM yang dilakukan Petani Garam.

Pada tahap selanjutnya yaitu tahap penyaluran dana bantuan PUGAR masyarakat (petambak garam) tidak semua mengetahui alur mekanisme pemberian dana bantuan karena hanya ketua kelompok, Tim Teknis PUGAR dan Tim Pendamping PUGAR Dinas Kelautan dan Perikanan Kab.Sumenep serta dibantu perangkat desa yakni Kepala Desa dan Kecamatan yang mendapatkan pengarahan dan sosialisasi langsung dari tim teknis PUGAR dan Tim Pendamping PUGAR yang dibentuk Dinas Kelautan dan Perikanan Kabupaten 
Sumenep. Pada tahap ini tim Tim Teknis PUGAR dan Tim Pendamping PUGAR Dinas Kelautan dan Perikanan Kab.Sumenep mengumpulkan ketua kelompok untuk menjelaskan mengenai , yang isinya mengenai keinginan dan rincian para petambak garam dalam memanfaatkan dana bantuan tersebut dan proposal rencana usaha bersama (RUB) kebutuhan dari petani garam untuk mengajukan besaran nominal dana bantuan PUGAR.

Dana Progam Pemberdayaan Usaha Garam Rakyat ( PUGAR ) dalam pencairan dana yang dilakukan bertahap meliputi tahap pertama adalah 50 persen, tahap kedua adalah 40 persen, tahap 3 adalah 10 persen. Besaran dana bantuan yang diterima pun juga beragam. Untuk kugar lama maksimal bantuan yang diterima sebesar Rp 12.500.000, sedangkan untuk kugar baru maksimal Rp 40.000.000.

Di dalam mekanisme program PUGAR tersebut dijelaskan bahwa petambak garam diharuskan membuat proposal sebagai syarat untuk menerima bantuan tersebut. Setelah itu proposal tersebut dikumpulkan secara kolektif oleh tim pendamping dan diserahkan ke tim Tim Teknis PUGAR Kelautan dan Perikanan Kab.Sumenep untuk dikoreksi, dievaluasi dan selanjutnya disetujui oleh kepala Dinas Kelautan dan Perikanan Kabupaten Sumenep dan dikeluarkannya SK bagi kelompok petani garam (KUGAR) yang berhak mendapatkan dana PUGAR. Pada tahap pencarian dana bantuan ketua kelompok harus membuat rekening bank pada bank yang telah ditunjuk agar dana tersebut dapat langsung diterima oleh petambak garam di beberapa desa Kab.Sumenep. Ini dilakukan supaya dana bantuan dapat diterima langsung oleh petambak garam secara utuh dan dimanfaatkan sendiri oleh para petambak garam.

Bantuan Langsung Masrakat (BLM) yang akan diberikan kepada semua kelompok petani garam. Sisanya akan digunakan sebagai anggaran untuk kegiatan pendukung teknis Program PUGAR seperti kegiatan sosialisasi, Lokakarya pembinaan ke petani garam, review (evaluasi) pelaksanaan Pugar, biaya konsultan manajemen, dan adminustrasi kegiatan.

Penetapan Dana PUGAR tahun 2013 lebih kecil karena dibagi menjadi dua ketegori. Pertama sekitar 17 kelompok baru dengan bantuan sebesar Rp 40 juta perkelompok. Kedua kategori kelompok lama sebanyak 153 kelompok dengan nilai bantuan perkelompok $\mathrm{Rp}$ 12,5 juta. Sementara pada tahun 2013 ini semua kelompok adalah kelompok lama yang nilai bantuannya bisa sama rata.

Permasalahan utama pada produksi garam ditingkat petani garam lokal antara lain adalah infrastruktur, kebutuhan hidup petani sehari - hari, dan pasar pemasaran garam. masalah ini menghambat produksi garam rakyat. Infrastruktur sangat menghambat petambak garam rakyat untuk mendapatkan air laut, hal ini disebabkan adanya pendangkalan lahan garam, mengalirkan air ke petak lahan garam dan alat mempercepat pembentukan kristal garam, sehingga produksi garam milik petani garam lokal mengalami hambatan. Identifikasi dan seleksi terhadap proposal yang masuk ke Dinas Kelautan dan Perkanan Kabupaten Sumenep pertama kali dilakukan oleh Tenaga Pendamping, baik secara administrasi maupun pengecekan kelapangan survei lahan apakah lahan milik petani garam dan bukti sewa lahan milik PT.GARAM yang dilakukan Petani Garam., sekaligus verifikasi langsung kepada kelompok pengusul, pembagian maupun pengalokasian besaran dana Bantuan PUGAR perkelompok, pembentukan kelompok petani garam (KUGAR), kemudian dilaporkan ke Tim Teknis Kegiatan PUGAR tahun 2013 Kabupaten Sumenep Adapun jumlah kelompok yang memperoleh BLM PUGAR pada tahun 2013 sebanyak 366 kelompok dan 1 gabungan kelompok 
dengan jumlah anggota sebanyak 3.534 orang, yang terdiri dari kelompok baru sebanyak 471 kelompok dan kelompok lama Tahun 2011 dan tahun 2012 sebanyak 3.063 kelompok.

Berikut Penjelasan dari tahapan Pemberdayaan Usaha Garam Rakyat (pugar) berdasarkan Konsep Pemberdayaan menurut Friedmann adalah

a) Defensible Life space atau ruang hidup dipertahankan dan aktifitas pendukung kehidupan lainnya berlangsung, Petani penggarap memperoleh bagian $30 \%$ dari jumlah penjualan hasil panen garam yang dari pemilik lahan garam dan $70 \%$ sisanya diberikan kepada pemilik lahan garam. Fakta yang ditemukan dilapangan dimana pihak yang lebih merasa berkepentingan dengan kualitas garam adalah petani penggarap lahan garam, pemilik lahan garam dan pedagang perantara atau tengkulak yang berpengaruh secara langsung pada keuntungan yang akan diraup.

Mulai tahun 2011 bergulirnya Dana Bantuan PUGAR, petani garam rakyat Kabupaten Sumenep lebih mengandalkan dana dari PUGAR yang disalurkan melalui rekening petani garam rakyat. Keterbatasan pendapatan dari hasil panen garam dan modal awal untuk memulai proses produksi garam.

b) Surplus time atau Surplus waktu, Sebelum menjalankan Pelaksanaan program Pendampingan dilakukan oleh Tim Pendamping Dinas Kelautan dan Perikanan Kabupaten Sumenep ke petani garam rakyat, hendaknya tenaga pendamping ini memperoleh arahan mengenai tugas dan fungsi selama Satu hingga dua minggu dari Dinas Kelautan dan Perikanan Kabupaten Sumenep, sehingga mampu melaksanakan kegiatan pendampingan. Kemampuan untuk mempertahankan usaha garam rakyat secara turun temurun dilakukan petani garam rakyat di Kabupaten Sumenep dengan mengandalkan tenaga kerja yang melayani tanpa harus dibayar yakni Keluarga Petani garam rakyat.

c) Knowledge and skills atau pengetahuan dan keterampilan, Tingkat pendidikan petani garam rakyat untuk menerima dan mencari informasi sangat berbagai ragam. Petani pemilik lahan garam yang menyerahkan sepenuhnya lahannya kepada tenaga penggarap lahan garam umumnya adalah pengusaha atau perangkat pemerintah dengan tingkat pendidikan SMA dan S1, Sedangkan tenaga penggarap lahan garam memiliki tingkat pendidikan SMP dan SD. Berdasarkan tingkat pengalaman kerja, 70 persen petani garam rakyat di Kabupaten Sumenep telah bekerja sebagai petani garam lebih dari 10 tahun.

Upaya Dinas Kelautan dan Perikanan ingin mensosialisasikan dan memberikan informasi mengenai program PUGAR ini dengan cara mengandalkan tenaga pendamping untuk mengadakan Pertemuan kelompok dilakukan dua kali dalam seminggu (hari Sabtu dan Minggu) turun ke Desa - Desa menjumpai ketua kelompok KUGAR dan Kepala Desa (atau yang mewakili) setempat. Kehadiran Tenaga Pendamping itu sangat penting sesuai dengan fungsinya masing-masing, yaitu: 1) Tenaga Pendamping menyampaikan informasi (materi penyuluhan); 2) ketua kelompok KUGAR memberi suasana keterikatan emosional serta siap memberikan informasi.

d) Appropriate information atau pemberian informasi yang tepat. persoalan paling pokok yang dikeluhkan oleh anggota kelompok petani garam rakyat (KUGAR) dan kelompoknya adalah intensitas kehadiran dan keberadaan pendamping itu sendiri di lokasi atau di tempat mereka (kelompok sasaran program), 
justru ada sebagian anggota kelompok petani garam rakyat (KUGAR) yang tidak mengenal pendampingnya. Kondisi tersebut merupakan akibat pola perekrutan yang salah (pendamping yang belum berpengalaman melakukan peranperan pendampingan). Mekanisme insentif sering mempengaruhi intensitas kehadiran pendamping di lokasi kelompok, dan sering dikeluhkan oleh tim pendamping PUGAR Dinas Kelautan dan Perikanan Kabupaten Sumenep, Hal ini mengakibatkan tim pendamping Dinas Kelautan dan Perikanan Kabupaten Sumenep jarang berada ditempat saat dibutuhkan oleh kelompok. Dalam proses pendampingan selama enam bulan, pendamping mendapat pembayaran dua kali per tiga bulan. Dalam suatu wilayah kabupaten Sumenep hanya ditempatkan dua orang tenaga pendamping yang bertugas mendampingi kegiatan kelompok usaha garam rakyat (KUGAR).

e) Social organizations/organisasi sosial. Dinas Kelautan dan Perikanan Kabupaten Sumenep dibantu dengan Tenaga Pendamping Dinas Kelautan dan Perikanan Kabupaten Sumenep serta Kepala Desa Sebagai Perangkat Desa dan Ketua Kelompok petani garam menyalurkan dan mengecek apakah Dana Progam Pemberdayaan Usaha Garam Rakyat (PUGAR) sudah bertahap dalam pencairannya ke anggota petani garam. Saat pengajuan proposal dan pencairan dana dana bantuan PUGAR harus menyertakan tanda tangan Kepala Desa dan ketua kelompok. stakehoder atau instansi yang ikut terlibat dalam membongkar penyelewengan dana bantuan PUGAR di Kabupaten Sumenep Dinas Kelautan dan Perikanan Kabupaten Sumenep dan Kejaksaan Negeri (Kejari) Sumenep melakukan penyelidikan penyelewengan dana
PUGAR di Kabupaten Sumenep. Dalam tingkatan DPRD Sumenep membentuk panitia kerja (panja) untuk menyelesaikan penyelewengan dana PUGAR Kab.Sumenep.

f) Social networks/jaringan sosial. Ketua kelompok usaha garam rakyat (KUGAR) dianggap sebagai seorang pemimpin oleh petani sehingga harus dihormati dan dipatuhi. Berdasarkan intensitas pengaruh ketua kelompok tani terhadap sikap petani dalam pengelolan tergolong tinggi yang artinya peran ketua kelompok tani berpengaruh 100 persen terhadap sikap anggota kelompok usaha garam rakyat (KUGAR) terutama berkaitan dengan pengambilan keputusan dalam pembagian dana bantuan PUGAR ke setiap anggota kelompok, mengawasi kadar air maupun kadar kepekaan dari garam itu sendiri, besaran berat per karung garam yang akan dijual ke tengkulak dan hasil panen garam ini akan dijual ke perusahaan pengelolaan atau ke Koperasi Garam Astagina Kabupaten Sumenep.

Kemitraan usaha garam rakyat antara pedagang perantara atau tengkulak dengan Petani Garam Rakyat telah berjalan cukup baik, meski cenderung merugikan Petani Garam Rakyat, karena pembayaran dilakukan setelah pedagang eceran berhasil menjual semua hasil panen garam. Uang penjualan setiap petak hasil panen garam kemudian masih dibagi sama kepada semua anggota kelompok. Pada ahirnya, setiap anggota hanya mendapatkan hasil penjualan yang relatif kecil,

g) Instruments of work and livelihood / instrumen kerja dan mata pencaharian. Secara umum pendapatan petani tambak garam diperoleh dari empat sumber pendapatan yaitu sumber pendapatan tambak garam, perikanan, toko sembako dan guru atau PNS. Struktur sumber pendapatan masyarakat petani tambak tidak 
semuanya melakukan aktivitas usaha tersebut, ada beberapa petani yang mempunyai lebih dari dua sumber pendapatan. Pada umumnya petani garam di Desa Pnggir Papas, Desa Kalianget, Desa Karang Anyar dan Desa Gersik Putih tidak menggantungkan pendapatan mereka sepenuhnya pada usaha garam. Responden yang mempunyai penghasilan dari dua sumber pendapatan yaitu dari usaha garam dan perikanan budidaya. Kegiatan perikanan budidaya dilakukan pada saat pada musim penghujan yaitu memanfaatkan lahan tambak garam sebagai kegiatan usaha budidaya ikan bandeng dan udang. Kegiatan usaha sembako setiap harinya kebanyakan dilakukan oleh istri dan dibantu oleh suaminya pada saat waktu luang.

h) Financial resources atau sumber daya keuangan. Perusahaan Pengolahan dan Perusahaan pengumpul besar memperoleh harga beli garam per tonnya dari pedagang perantara jauh lebih murah (Rp.325.000) komponen terbesar terletak pada sewa lahan dengan harga kisaran 5.000.00010.000.000 per hektar tergantung dengan luas lahan dalam kurun waktu setiap tahunnya. Berikut rincian sumber pengeluaran dari usaha garam rakyat di Kabupaten Sumenep yang dihimpun oleh penulis pada tabel 1 .

Tabel 1. Rincian pengluaran usaha garam

\begin{tabular}{|c|c|}
\hline $\begin{array}{c}\text { Biaya } \\
\text { persiapan }\end{array}$ & Biaya (Rp) \\
\hline $\begin{array}{l}\text { Perbaikan } \\
\text { Saluran dan } \\
\text { tanggul }\end{array}$ & $\begin{array}{l}\text { (1 orang } \times \text { 5hari } \times \mathrm{Rp} \\
20.000 \\
\text { Rp. } 100.000\end{array}$ \\
\hline $\begin{array}{l}\text { Kincir Angin } \\
\text { jika Rusak }\end{array}$ & $\begin{array}{l}2 \text { buah x Rp. } 20.000 \text { Rp. } \\
40.000\end{array}$ \\
\hline Meja Garam & $\begin{array}{l}\text { 1orang x 5hari x } \\
\text { Rp20.000) Rp. } \\
100.000\end{array}$ \\
\hline $\begin{array}{l}\text { Biaya } \\
\text { pengisian } \\
\text { garam ke } \\
\text { karung }\end{array}$ & $\begin{array}{l}3 \text { orang x } 25.000 \text { per } \\
\text { ngisi) Rp. } 75.000\end{array}$ \\
\hline
\end{tabular}

\begin{tabular}{|l|l|}
\hline $\begin{array}{l}\text { Biaya } \\
\text { pengisian } \\
\text { garam ke } \\
\text { karung }\end{array}$ & $\begin{array}{l}\text { 3 orang } \times 25.000 \text { per } \\
\text { ngisi Rp. } 75.000\end{array}$ \\
\hline $\begin{array}{l}\text { Biaya Angkut } \\
\text { garam sampai } \\
\text { ke truk }\end{array}$ & $\begin{array}{l}\text { 3 orang x 20.000 x } 8 \\
\text { karung) } \\
\text { Tp. 480.000 }\end{array}$ \\
\hline \multicolumn{1}{|c|}{ Total } & \multicolumn{1}{|c|}{ Rp. $\mathbf{7 9 5 . 0 0 0}$} \\
\hline
\end{tabular}

Berdasarkan Pada tabel diatas, penulis menjelaskan biaya yang dikeluarkan dalam proses pembuatan garam mulai dari lahan sampai dengan tenaga penggrap dengan menghabiskan biaya sebesar Rp. 795.000, biaya perbaikan kincir angin sebesar Rp. 40.000 dan biaya perbaikan lahan garam retak-retak atau meja garam dengan mengunakan satu tenaga orang. Pada perbaikan saluran dan tanggul, kincir angin, serta meja lahan garam ini hanya dilakukan oleh satu tenaga kerja.

Biaya lain yang dikeluarkan pada usaha tambak garam adalah biaya pengisian garam ke dalam karung, biaya angkut garam dan upah. Besarnya biaya pengisian garam adalah Rp. 75.000 untuk tenaga 3 orang setiap pengisian 8 karung garam. Jumlah produksi garam dalam satuan karung yang diperoleh dengan metode maduris adalah 8-10 karung garam dengan proses pengisian sebanyak 8-10 kali pengisian . besarnya biaya angkut garam sebesar Rp. 480.000 dengan tiga orang tenaga. Proses pengangkutan garam ini dilakukan dari lahan garam sampai ke jalan raya kemudian sampai dengan truk membutuhkan 3 orang tenaga kerja dengan bayaran sebesar Rp. 20.000 . dalam mengangkut garam biasanya para pengangkut menggunakan bantuan motor yang merupakan milik mereka sendiri.

Bagi usaha tambak garam rakyat, lahan merupakan investasi yang paling penting karena menyangkut keberlangsungan usaha. Petani yang memiliki lahan garam $>1$ ha pada umumnya memiliki kemampuan 
ekonomi yang baik sehingga dalam masyarakat memiliki status sosial yang tinggi dan pengelolaan lahan dilakukan oleh penggarap, sedangkan pemilik lahan sempit dengan luasan $<1$ ha menggarap lahannya sendiri dengan dibantu satu orang penggarap.

Produksi yang melimpah ternyata tidak sebanding dengan jumlah keuntungan yang diperoleh petani garam. Ketika hasil berlimpah tepatnya saat panen raya, para pedagang yang disebut pengumpul berusaha membeli garam dengan harga murah, tidak langsung dijual ke konsumen tetapi ditimbun/ disimpan dahulu. Baru dilempar kepasaran pada saat harga tinggi, sehinga keuntungannya pasti berlipat dari harga belinya dahulu. Dari tahun ketahun memang ada peningkatan harga jual garam setiap kilogramnya, berikut pendapatan petani garam dari hasil penjualan garamnya adalah

Tabel harga garam dan jenis kualitas garam

\begin{tabular}{|c|c|r|}
\hline No & Jenis garam & Total \\
\hline A & Garam KP 1 (35 ton $x$ & 16625 \\
& Rp 475 000) & 000 \\
\hline B & Garam KP 2 (35 ton $x$ & 11375 \\
& Rp 325 000) & 000 \\
\hline C & Garam KP 3 (15 ton $x$ & 4125 \\
& Rp 275 000) & 000 \\
\hline
\end{tabular}

Berdasarkan Pada tabel diatas, penulis menjelaskan bahwa Harga jual garam untuk kualitas 1 (KP 1) adalah berkisar Rp.400-Rp550/kg garam, untuk kualitas 2 (KP 2) sekitar Rp250Rp400/kg dan kualitas 3 (KP 3) sebesar Rp200-Rp350/kg garam. Harga penjualan yang diperoleh pedagang pengumpul baik dari perusahaan pengolah maupun koperasi adalah untuk kualitas 1 sebesar Rp580-Rp600/kg, kualitas 2 sebesar Rp325-Rp450/kg dan kualitas 3 berkisar antara Rp250Rp375/kg garam.

Tidak hanya masalah harga yang ditentukan secara sepihak oleh pedagang pengumpul, namun adanya kecurangan juga yang dilakukan ketika perhitungan berat garam tidak sesuai ukuran karung yang digunakan. Semua pedagang pengumpul mengukur secara rata 1 ton sama dengan 20 karung, dengan asumsi berat 1 (satu) karung sama dengan $50 \mathrm{~kg}$ garam. Padahal kenyataannya, dalam 1 (satu) karung pedagang pengumpul dapat mengisi sampai dengan 60-70 kg garam, tentu saja hal ini sangat merugikan petani.

Kendala lainnya terutama pada aspek pendapatan kelompok usaha garam rakyat (KUGAR) sangat dipengaruhi oleh musim kemarau yang panjang sekitar $6-7$ bulan dapat menghasilkan garam rakyat yang sangat banyak.

\section{Pelaksanaan Pemberdayaan Usaha Garam Rakyat (PUGAR) Di Kabupaten Sumenep.}

\begin{tabular}{lllr} 
Dala & tahap & ini & penulis \\
mengkaitkan & dengan & nilai & yang \\
terkandung & dalam & \multicolumn{2}{c}{ Implementasi }
\end{tabular} kebijakan publik grindle yakni Konteks Kebijakan (Policy Context) atau pelaksana kebijakan. Kementerian Kelautan dan Perikanan (KKP), Kementerian Perindustrian, Kementerian Perdagangan dan Kementerian Koordinasi Perekonomian melalui rapat Kementerian Koordinator Bidang Perekonomian sesuai dengan Keputusan Menteri Koordinator Bidang Perekonomian Nomor KEP-11 / M.EKON /03 / 2011 tentang Tim Koordinasi Swasembada Garam Nasional membahas kuota garam yang akan diimpor, masa berlangsungnya impor garam dan perusahaan mana yang akan mengimpor garam dan menetapkan harga pokok penjualan (HPP) garam, penyaluran dana PUGAR, hasil garam yang dihasilkan oleh kelompok usaha garam rakyat (KUGAR) .

Peran Petani garam rakyat adalah bagian dari masyarakat pesisir yang merupakan masyarakat yang termarginalkan dan memproduksi garam rakyat sehingga sesuai dengan UU 
Nomor 27 Tahun 2007 tentang Pengelolaan Wilayah Pesisir dan PulauPulau Kecil. Kementerian Kelautan Perikanan (KKP) wajib mendorong berbagai kegiatan usaha petani garam (KUGAR) termasuk pengelolaan garam.

Menurut Peraturan Menteri Perdagangan (Permendag) Nomor 58/MDAG/PER/9/2012 ini hanya menyebutkan pemerintah menunjuk PT Garam untuk melakukan dan mengawasi impor garam yang dilakukan perusahaan swasta, memproduksi garam sendiri guna memenuhi kebutuhan garam industri secara nasional dan mencukupi perusahaan industri swasta yang mengunakan garam industri yang tidak mengimpor sendiri.

Pada prinsipnya pelaksanaan PUGAR tahun 2013 sama dengan PUGAR tahun sebelumnya, antara lain dalam hal penyaluran BLM, seleksi calon penerima dan lokasi, mekanisme penetapan tenaga pendamping, sosialisasi, pemanfaatan BLM serta mekanisme pelaporan. Penerima PUGAR tidak mudah karena harus diverifikasi terlebih dulu. pemetaan lahan garam dan verifikasi lahan garam yang dilakukan oleh Tenaga Pendamping dan Tim teknis PUGAR Dinas Kelautan Perikanan Kabupaten Sumenep. Sebaliknya, pada setiap tahunnya Proses pemetaan lahan dan menetapkan daftar nama kelompok petani garam rakyat yang mendapatkan dana bantuan ini membutuhkan waktu satu bulan. Lalu, masing-masing pendamping bersama tenaga pendamping dan tim teknis PUGAR Dinas Kelautan dan Perikanan Kab.Sumenep, mengajukan data kepada tim verifikasi untuk dilakukan verifikasi.. Jadi untuk waktu pencairan dananya, menunggu semua proses tersebut tuntas. setelah semua data dari Tenaga Pendamping dan Tim teknis PUGAR Dinas Kelautan Perikanan Kabupaten Sumenep dianggap lengkap, baru Dinas Kelautan Perikanan Kabupaten Sumenep ini mengajukan pencairan dana PUGAR pada
Kementerian Kelautan dan perikanan RI. Dinas Kelautan dan Perikanan Kab.Sumenep tidak bisa begitu saja mencairkan dana PUGAR tersebut dikarenakan Semua bergantung kepada Kementerian Kelautan dan perikanan RI pusat.

Dalam penelitian ini, selain Dinas Kelautan dan Perikanan Kabupaten Sumenep, juga terdapat tokoh panutan lain yaitu Kepala Desa yang selalu memberikan bimbingan, pengarahan, saran bahkan pendapat kepada petani berkaitan dengan permasalahan yang dihadapi oleh petani garam disekitar desa tersebut. pengaruh Kepala Desa dalam program kemitraan PT Gudang Garam berada dalam kategori tinggi yaitu Kepala Desa berpengaruh terhadap perubahan sikap petani dalam program kemitraan. Saran, pendapat atau ajakan dari Kepala Desa dipatuhi oleh petani karena Kepala Desa termasuk tokoh masyarakat yang disegani dan dihormati oleh petani sehingga mereka menerima saran, ajakan atau pendapat dari Kepala Desa tersebut.

Ketua kelompok tani seperti halnya Bapak Muhap selaku petani garam rakyat Desa Gersik Putih Kabupaten Sumenep sebagai ketua kelompok petani adalah seseorang yang diakui atau memperoleh pengakuan dari anggota kelompoknya yang dipilih secara mufakat untuk menggerakkan anggotanya mencapai tujuan bersama yang telah dirumuskan.

Petugas Teknis dan Tim Teknis PUGAR Dinas Kelautan dan Perikanan Kabupaten Sumenep menyampaikan materi penyuluhan. Materi yang disampaikan akan diterapkan pertama kali oleh Kontak tani (Figur Desa atau Kepala Desa maupun ketua Kelompok Usaha Garam Rakyat (KUGAR) ), karena biasanya petani garam ingin melihat bukti nyata dari materi yang disampaikan secara teoritis. Secara formal kepala desa merupakan penanggung jawab utama ke Kelompok Usaha Garam Rakyat (KUGAR) yang diketuai oleh Ketua 
Kelompok Usaha Garam Rakyat (KUGAR). Melalui Kelompok Usaha Garam Rakyat (KUGAR), anggota kelompok Usaha Garam Rakyat (KUGAR) mengambil kesepakatan tentang pelaksanaan materi penyuluhan.

Peran Ketua Kelompok Usaha Garam Rakyat (KUGAR) ini mencari perusahaan swasta/perusahaan negara/ koperasi yang akan menampung hasil panen garamnya. Selanjutnya anggota Kelompok Usaha Garam Rakyat (KUGAR) berkerjasama dengan Ketua Kelompok Usaha Garam Rakyat (KUGAR), dalam hal penyediaan sarana produksi dan pemasaran produk. ada beberapa hal yang menjadi penyebab tidak lancarnya program pemberdayaan usaha petani garam rakyat (PUGAR) ini. Terdapat dua diantaranya, adalah karena prasangka keruangan (pada umumnya tenaga Pendamping dan Tim Teknis PUGAR Dinas Kelautan dan Perikanan Kabupaten Sumenep) lebih memilih lokasi yang dekat dengan kota dengan kondisi infrastruktur (sarana jalan) yang baik daripada daerah terpencil sehingga tidak terjangkau program dana PUGAR ini.

Peran Paguyuban Petani Garam Rakyat Sumenep (Perras) adalah adalah mencatat hasil produksi garam setiap tahunnya, memprediksi hasil panen garam rakyat berdasarkan luas lahan petani garam rakyat di Sumenep yang tersebar di 8 Kecamatan, setiap tahunnya PERRAS ini selalu memprediksi hasil panen garam seperti tiap lahan produksi garam diasumsikan 90 ton, maka jumlah produksi garam rakyat di Kab.Sumenep secara keseluruhan selama setiap musim dengan masa produksi 5-6 bulan mencapai mencapai sekitar 500 ton. Fungsi lain dari Paguyuban Petani Garam Rakyat Kab.Sumenep (PERRAS) mengenai berfungsi menjembatani permasalahan yang dihadapi pihak petani garam rakyat dengan Pihak Pemerintah kabupaten Sumenep, pihak Koperasi Astagina, pihak Persuhaan Swasta
PT.Garindo dan Perusahaan BUMN PT.GARAM mengenai rendahnya harga jual garam rakyat pada musim produksi setiap tahunnya dan daya serap perusahaan tersebut.

Dampak yang diperoleh dari program PUGAR menurut Implementasi Kebijakan Grindle adalah Impact on society, individuals, and groups adalah pihak yang terkena dampak kebijakan baik secara langsung maupun tidak langsung. Pada tahun 2012 produksi garam nasional mencapai 2.473.716 ton, dari luasan lahan 26,95 hektar dengan produktivitas mencapai 91,7 ton/hektar. Sementara produksi garam Pugar secara nasional pada tahun 2012 meningkat dratis hingga mencapai 2.020.109 ton dengan produktivitas 96,79 ton/hektar dari luas lahan sebesar 20.870 hektar dengan masa produksi selama 5-6 bulan dari bulan juli hingga januari.

Pada tahun 2011, Kementerian Kelautan dan Perikanan memberikan dana tugas pembantuan untuk Program Usaha Pemberdayaan Garam Rakyat utntuk Kabupaten Sumenep sebesar Rp. 5.835.000.000 Penerima Bantuan Langsung Masyarakat ( BLM ) Program PUGAR Tahun 2011 di Kab. Sumenep adalah sebanyak 130 Kelompok Usaha Garam Rakyat ( KUGAR ) yang terdiri dari 1300 Petambak Garam di 28 desa pada 8 kecamatan, Berdasarkan data yang bisa dihimpun dari tim pendamping PUGAR Dinas Kelautan dan Perikanan Kabupaten Sumenep hingga bulan Nopember 2011 tecatat bahwa Produksi Garam di Kab. Sumenep pada Tahun 2011 baik dari PUGAR maupun non PUGAR sebesar : 85.449 Ton dan \pm 50.000 Ton, PT. Garam sebesar 140.000 Ton. Pendapatan petambak garam setelah mendapat PUGAR sebesar Rp. 3.500 .000 /Ha /Tahun dengan rata-rata produksi 6 Ton /Ha /Tahun dengan harga rata-rata Rp. 350.000 - 550.000/Ton.

Penerima Bantuan Langsung Masyarakat (BLM) Program PUGAR Tahun 2012 di Kabupaten Sumenep 
sebanyak 330 (Tiga Ratus) Kelompok Usaha Garam Rakyat (KUGAR) yang terdiri dari 221 (Dua Ratus Dua Puluh Satu) kelompok baru dan 109 (Seratus Sembilan) kelompok lama / KUGAR 2011. Sedangkan jumlah Petambak Garam yang tergabung dalam KUGAR di 38 desa pada 12 kecamatan sebanyak 3.222 orang, hingga 31 Desember 2012 telah terealisasi penyaluran BLM Program PUGAR sebesar Rp. 8.600.500.000,- (Delapan Milyar Enam Ratus Juta Lima Ratus Ribu Rupiah). Pendapatan petambak garam setelah mendapat PUGAR tahun 2012 rata - rata sebesar \pm Rp. 17.500 .000 $/ \mathrm{Ha} /$ Tahun dengan rata-rata produksi \pm 40-70 Ton/Ha/Tahun dengan harga $\pm \mathrm{Rp}$. 250.000 - Rp. $600.000 /$ Ton.

Penerima Bantuan Langsung Masyarakat (BLM) Program PUGAR Tahun 2013 di Kab. Sumenep sebanyak 366 (Tiga Ratus Enam Puluh Enam) Kelompok Usaha Garam Rakyat ( KUGAR ) dan satu Gabungan Kelompok Usaha Garam Rakyat (BUNG KUGAR) yang terdiri dari 316 (Tiga Ratus Enam Belas Ribu) kelompok baru dan 50 (Lima Puluh) kelompok lama terdiri dari KUGAR 2011 dan KUGAR 2012. Sedangkan jumlah Petambak Garam yang tergabung dalam KUGAR di 38 desa pada 12 kecamatan sebanyak 3.534 orang dengan perincian 471 orang kelompok baru dan 3.063 kelompok lama hingga 31 Desember 2013 telah terealisasi penyaluran BLM Program PUGAR sebesar Rp. 3.600.000.000,- (Tiga Milyar Enam Ratus Juta Rupiah ) atau sebesar $100 \%$. Adapun jumlah kelompok yang memperoleh BLM PUGAR pada tahun 2013 sebanyak 366 kelompok dan 1 gabungan kelompok dengan jumlah anggota sebanyak 3.534 orang, yang terdiri dari kelompok baru sebanyak 471 kelompok dan kelompok lama Tahun 2011 dan tahun 2012 sebanyak 3.063 kelompok. Hasil Produksi Garam dari Kelompok Usaha Garam Rakyat
(KUGAR) tahun 2013 Kabupaten Sumenep sebanyak 97.329,86 ton.

Cakupan kerja di Kabupaten Sumenep pada tahun 2013 diharapkan bertambah, seperti telah disampaikan bahwa pada tahun 2012 wilayah kecamatan yang mendapatkan Program PUGAR terdiri dari 11 Kecamatan, yakni Kecamatan. Paragaan, Giligenting, Saronggi, Kallianget, Talango, Kota Sumenep, Gapura, Dungkek, Ra'as, Arjasa dan Sapeken.

Pada tahun 2013 diharapkan ada penambahan satu kecamatan lagi, yakni Kecamatan Kangayan dengan desa yang diharapkan mendapatkan bantuan PUGAR adalah Desa Batuputih, Saobi, Cangkramaan dan Tembayangan. Sebenarnya tanah - tanah di desa tersebut apabila dialiri Air Laut langsung bisa jadi Garam meskipun tidak berbentuk petakan - petakan sebagaimana Tambak Garam pada umumnnya,

Penulis menyimpulkan Keluaran yang diperoleh dari program PUGAR adalah Program Pugar sangat bagus untuk membantu permodalan petani garam rakyat di Kabupaten Sumenep. Akan tetapi, Program PUGAR ini tidak dbantu dengan harga penjualan garam milik petani garam sangat rendah. Untuk garam kualitas satu (K1) hanya berkisar Rp 540550 per $\mathrm{kg}$, padahal harga patokan pemerintah Rp 750 per kg. Untuk harga garam Kualitas 2 (K2) kurang dari Rp 400 per $\mathrm{kg}$ padahal harga garam milik petani rakyat kualitas 2 (K2) yang ditetapkan pemerintah sebesar Rp.550 per kg. Tanpa memperbaiki harga di tingkat petani, program PUGAR itu menjadi tidak berguna.

Kemitraan Pemangku Kebijakan
dalam mengimplementasikan Program
Dana Bantuan Pemberdayaan Usaha
Garam Rakyat (PUGAR)
Dinas Kelautan dan Perikanan
$\begin{aligned} & \text { Kabupaten } \\ & \text { melaksanakan program PUGAR di } \\ & \text { beberapa desa Kabupaten Sumenep }\end{aligned}$ 
adalah melakukan pendekatan informal kepada petani pengelola tanah milik desa yang akan lokasi program PUGAR digulirkan, menjelaskan mengenai Lokakarya PUGAR dan pendataan kelompok Usaha Garam Rakyat untuk mendapatkan bantuan dana PUGAR. Pendekatan ini meliputi penyebaran informasi tentang Lokakarya dan Dana Bantuan Pugar latar belakang dan tujuan PUGAR ke kelompok Usaha Garam Rakyat (KUGAR), aturan kerja PUGAR serta petunjuk teknis lainnya. Sedangkan bagi para tokoh Desa dan Kelompok Usaha Garam Rakyat disekitar daerah lain, mereka dibawa dan diajak oleh petugas teknis PUGAR Dinas Kelautan dan Perikanan Kabupaten Sumenep dan Tim pendamping Dinas Kelautan dan Perikanan Kabupaten Sumenep ke daerah lain yang sudah melaksanakan Lokakarya dan PUGAR. Tujuannya adalah untuk memperlihatkan secara langsung hasil yang telah dicapai dengan adanya Lokakarya atau PUGAR, dengan harapan mereka akan menginformasikan pengetahuannya itu kepada petani garam lain. Tahap penyebaran informasi ini dilakukan secara bersama maupun terpisah oleh petugas teknis PUGAR Dinas Kelautan dan Perikanan Kab.Sumenep dan Tim pendamping Dinas Kelautan dan Perikanan Kabupaten Sumenep, Tokoh Informal desa dan Kepala Desa.

Pertemuan yang sangat penting adalah pertemuan kelompok usaha garam rakyat dbertempat tinggal didesa yang sama pada saat menjelang musim tanam. Dalam pertemuan ini dibicarakan masalah keseragaman komoditi yang akan diusahakan dan keseragaman musim tanam, anggaran untuk memperbaiki lahan dan membeli alat pengolahan garam yang telah rusak serta anggaran tersebut diperoleh dari urunan dan membuat proposal PUGAR untuk disodorkan ke Dinas Kelautan dan Perikanan Kabupaten Sumenep. Kelompok Usaha Garam Rakyat
(KUGAR) ini berperan besar dalam proses pembuatan garam rakyat secara gotong royong, keseragaman komoditi garam rakyat dan waktu memulai pembuatan garam rakyat, pemasaran hasil penjualan panen garam maupun bagi hasil penjualan panen garam dengan anggota kelompoknya. Serta ketua kolompok Usaha Garam Rakyat (KUGAR) sebagai tempat komunikasi dengan Dinas Kelautan dan Perikanan Kabupaten Sumenep jika terjadi permasalahan mengenai petani garam rakyat di beberapa desa Kabupaten Sumenep.

Fakta yang ditemukan dilapangan dimana pihak yang lebih merasa berkepentingan dengan kualitas garam adalah petani penggarap lahan garam, pemilik lahan dan tengkulak yang berpengaruh secara langsung pada keuntungan yang akan di didapat. Dari unsur pemilik lahan garam menginginkan produk garam dilahannya berkualitas tinggi karena pemilik lahan garam ini menyakini pada kondisi tersebut akan diperoleh keuntungan cukup besar. Sedangkan tenaga penggarap lahan garam tidak ingin ,membuat kualitas baik karena pada umumnya tidak percaya jika kualitas garam yang baik akan memberi keuntungan besar pada petani penggarap. Tenaga Penggarap lahan garam yang justru ujung tombak produksi garam rakyat berposisi semata-mata pada produsen yang tidak bersentuhan langsung dengan akses pasar. Sikap tenaga penggarap garam yang tidak responsif terhadap tuntutan kualitas garam menjadi satu hal tersendiri yang menarik.

Dalam mata rantai usaha garam rakyat di Kabupaten Sumenep, Melalui pola bagi hasil maka tenaga penggarap garam menerima pembayaran setengah sekitar $30 \%$ dari hasil panen, tenaga penggarap garam merupakan pihak yang paling kecil mendapatkan keuntungan. Tenaga Penggarap garam sangat tergantung dan ditentukan secara sepihak 
oleh pemilik lahan garam hanya memiliki hak untuk memproduksi garam dengan kewajiban menyerahkan sepenuhnya hak penjualan kepada pemilik lahan dan pemilik lahan yang menentukan harga. Adapun pemilik lahan garam hanya dapat menjual pada pedagang perantara tertentu dengan sistem kepercayaan yang terjalin cukup lama dan pedagang perantara tersebut cenderung menentukan harga secara sepihak.

Pedagang perantara memasok kebutuhan bahan baku dari petani ke perusahaan pengolahan atau ke pedagang pengumpul besar. Umumnya 1 orang pedagang perantara bekerjasama dengan 10-15 petani yang berada di 2-3 desa. Pedagang perantara membeli garam langsung ditambak-tambak petani atau gudang petani setiap 4-5 kali dalam sebulan selama musim panen garam (5 bulan).

Pedagang perantara melakukan proses grading, pengemasan dan pendistribusian garam dari tambak petani ke gudang kemudian setelah sesuai dengan kuantitas tertentu garam didistribusikan ke gudang pabrik pengolahan. Garam krosok yang dibeli dari petani dikemas dalam karung. Biaya pengangkutan garam berbeda tergantung jauh dekat lokasi tambak dengan jalan raya, apabila dekat dengan jalan raya biaya angkut dan pengemasan untuk 1 ton garam sebesar Rp 18 000, sedangkan apabila lokasi jauh sebesar Rp 20.000. Transaksi pembelian garam dari petani dilakukan setiap seminggu sekali dalam kurun waktu 5 bulan. pedagang perantara atau tengkulak mendatangi ke gudanggudang pemilik lahan yang berlokasi disekitar tambak garam. Proses penentuan harga garam disepakati bersama,

Penghasilan usaha garam sangat ditentukan oleh lima faktor utama. Pertama, luas area tambak garam yang dimiliki semakin banyak petakan lahan garam yang dimiliki oleh petani garam, semakin baik kualitas kadar garam yang dihasilkan atau produktifitas semakin banyak. Kedua, masa dan waktu panen garam yang dibutuhkan yang sangat menggantungkan diri pada musim kemarau. Jangka waktu panen usaha garam cukup beragam denga rata-rata 6 hingga 8 bulan dan masa petani garam memanen hasil garam didalam petak lahan garam minimal 6-8 hari sudah menjadi kristal garam memiliki kadar $\mathrm{NaCl}$ 95\%. Ketiga, kualitas garam yang dihasilkan petani garam sangat menentukan harga per/kg di pasaran atau kualitas kadar garam sangat ditentukan dengan berapa hari petani garam memanen garamnya minimal 6-8 Hari dan membutuhkan sinar matahari yang cukup. Jika didasarkan kualitas garam yang dihasilkan, sebagaian besar tambak garam di Kabupaten Sumenep menghasilkan kualitas garam curah Kualitas 2 (K2) dan kadang masih berwarna kehitaman yang banyak digunakan sebagai bahan baku industri pengawetan ikan. Keempat, model pemasaran yang dilakukan juga menjadi faktor penentu.

Tujuan pasar dari perusahaan besar termasuk PT. Garam dan PT. Garindo adalah industri pengguna/pengirim garam ke industri pupuk, pakan ternak dan industri pengasinan ikan, sehingga garam yang ditawarkan berbeda. Secara spesifik garam yang dibutuhkan untuk industri pengasinan ikan harus memiliki warna putih, butiran garam yang kecil dan mengandung kadar air tinggi, sedangkan untuk industri pakan ternak, jenis garam yang dibutuhkan tidak memperhatikan warna dan butiran garam yang besar. Kesulitan yang seringkali dihadapi pedagang perantara atau Tengkulak untuk memasok ke perusahaan pengolahan adalah tidak semua hasil produksi petani sesuai dengan spesifikasi yang diinginkan perusahaan pengolahan.

Pola kemitraan tata niaga garam di Kabupaten Sumenep yang dapat dilakukan adalah pola kemitraan Terpusat 
(Sentralisasi). Pola Terpusat (centralized model) adalah suatu model kemitraan yang klasik, dimana pembeli (koperasi Garam Astagina di Kabupaten Sumenep) membeli hasil panen dari banyak petani yang kemudian di kemasi dalam karung dan hasilnya dipasarkan. Persoalan krusial yang dihadapi PT. GARAM adalah lahan para petani garam yang terus bermasalah hingga kini. Para petani garam Kabupaten Sumenep itu hampir kehilangan lahannya, karena mediasi dengan PT Garam tidak berhasil.

PT Garam mempekerjakan buruh petani garam untuk menggarap lahannya dengan upah $\mathrm{Rp}$ 20.000-35.000 setiap pengerjaan, jauh di bawah kebutuhan hidup mereka. hubungan kurang baik antara PT Garam dengan petani garam rakyat. fakta dilapangan yang dijumpai penulis bahwa PT.Garam sangat merugikan Petani Garam. PT Garam hanya menawar atau membeli harga garam milik petani garam rakyat sangat rendah dan tidak sesuai ketentuan harga garam dari pemerintah. Tetapi bagi petani garam rakyat Sumenep harga garam sekitar Rp 400-500/kg sudah cukup, tanpa harus memperhatikan kualitas kadar $\mathrm{NaCl}$ garamnya dan tanpa berlakunya Kualitas 1 atau 2 pada garam rakyat.

\section{Faktor Pendukung dan Faktor Penghambat dari Implementasi Program Dana Bantuan Pemberdayaan Usaha Garam Rakyat (PUGAR)}

Dalam tahap ini penulis mengkaitkan poin dalam Implementasi Kebijakan Publik Grindle tentang Change and its acceptance, Tingkat perubahan yang terjadi serta penerimaan kelompok sasaran dan perubahan yang terjadi, target dan Sosialisasi. sebagian besar kelompok usaha garam rakyat (KUGAR) bahwa mereka tidak mengetahui mengenai program PUGAR dan proses pemberian dana bantuan karena pada Tahun 2011 2012 pelaksanaan sosialisasi hanya dilaksanakan tiga kali dalam satu bulan dan tidak semua kelompok usaha garam rakyat (KUGAR) mengikuti sosialisasi tersebut. Pada tahun 2011 - 2012 hanya ketua kelompok, tim pendamping PUGAR Dinas Kelautan dan Perikanan Kabupaten Sumenep dan kepala desa yang mengikuti sosialisasi yang diadakan Mulai tahun 2013 proses pencairan dana PUGAR selalu menghadirkan ketua, sekretaris , bendahara kelompok usaha garam rakyat (KUGAR) yang mendapatkan dana Program PUGAR dan Kepala Desa setempat. Hal ini bentuk antisipasi agar tidak ada penyalahgunaan bantuan program PUGAR diinternal Kelompok Petani Garam rakyat.

Lambannya proses penyaluran bantuan PUGAR ini juga dipengaruhi oleh tingkat pendidikan petani garam rakyat tidak mengerti cara pembuatan Proposal pengajuan PUGAR. Mayoritas umur petani contoh berada pada usia sekitar 40-50 tahun. Temuan ini memperkuat fenomena di Kabupaten Sumenep yang umum dalam tingkatan petani garam yang mengajukan proposal PUGAR didominasi oleh penduduk berumur tua, jika pun terdapat usia muda jumlahnya sangat sedikit. Tingkat pendidikan pemilik lahan garam sekaligus tenaga penggarap lahan garam memiliki tingkat pendidikan SMP dan SMA.. Berdasarkan tingkat pengalaman kerja, 70 persen petani garam rakyat di Kabupaten Sumenep telah bekerja sebagai petani garam lebih dari 10 tahun. Proposal pengajuan Dana PUGAR dari Petani Garam Rakyat yang diajukan kepada Dinas Kelautan dan Perikanan Kabupaten Sumenep tidak dilampiri dengan bukti sewa lahan PT. Garam. Hal itulah yang mengakibatkan Beberapa Petani Garam Rakyat tidak lolos menjadi penerima pugar yang dikelola Dinas Kelautan dan Perikanan Kabupaten Sumenep.

Dinas Keluatan dan Perikanan Kabupaten Sumenep setiap tahunnya 
menjadwalkan pencairan dana pemberdayaan usaha garam rakyat (Pugar) pada akhir Mei 2012 karena menggelar seleksi kelompok penerima pada April. Awal April Dinas Kelautan dan Perikanan Kab.Sumenep melakukan identifikasi calon kelompok penerima. Setelah identifikasi selesai, akan dilanjutkan dengan seleksi kelompok dan diteruskan dengan verifikasi pada awal Mei. Jika semua tahapan lancar, akhir Mei, dana Pugar setiap tahunnya sudah bisa dicairkan. Jika dana PUGAR ini cair sekitar bulan april maupun mei bisa membantu petani garam melakukan persiapan pembuatan lahan garam atau disebut bulan Pra produksi garam. Tahapan pra produksi ini meliputi pembenahan saluran air dan lokasi tambak dengan membuat pematang (tingkasa) dan pembentukan ulang dasar waduk, media peminihan lahan garam (air dingin,hangat dan panas) dan meja garam.

Bantuan pugar yang diberikan oleh pemerintah setelah para petani garam memanen garamnya. Akibatnya, para petani sudah tidak membutuhkan bantuan tersebut. Petani garam menginginkan agar bantuan pugar untuk petani garam harus tepat guna dengan membeli dan memperbaiki alat-alat pengelolaan garam rakyat, serta bantuannya untuk membangun infrastruktur lahan garam.

Dinas Kelautan dan Perikanan Kabupaten Sumenep sebagai lembaga yang menjalankan program dana PUGAR ini belum memiliki baseline data yang valid tentang luas lahan potensial, produksi, jumlah petambak garam dalam berbagai kategori (pemilik, penggarap, dll) dan keadaan awal masyarakat (tingkat pendapatan, pendidikan, keterampilan serta perilaku masyarakat) Sehingga permasalahan tersebut untuk kegiatan program PUGAR tahun 2014 harus dapat diantisipasi.

Penulis menyimpulkan didasarkan oleh pengamatan dilapangan bahwa
Kesulitan untuk mendapatkan data luas lahan, kepemilikan dan status lahan, hal ini disebabkan keterbatasan jumlah tenaga pendamping yang kurang memadai, serta letak Kecamatan yang sangat jauh dengan tempat tinggal dari Kelompok usaha garam rakyat (KUGAR) dan lahan tambak garam sebagian tersebar di wilayah kepulauan Kabupaten Sumenep

Anomali cuaca yang melanda berbagai daerah di Indonesia tahun 2010 dan 2013 lalu telah berdampak pada nasib petani garam. Dalam kondisi normal, penggarapan lahan garam seharusnya sudah dimulai sejak awal Juni,. Namun memasuki bulan agustus, lahan garam masih belum bisa diolah oleh petani garam. .

Kejaksaan Negeri (Kejari) Sumenep dan Dinas Kelautan Perikanan Kabupaten Sumenep menemukan dugaan korupsi dana yang beberapa kelompok usaha garam rakyat (KUGAR) yang mendapatkan dana PUGAR Rp. 50 juta, meskipun bantuan PUGAR turun, petani garam tidak mengunakan dana Program PUGAR untuk membeli peralatan pertanian garam.

Dalam penggunaan Dana PUGAR digulirkan ke petani garam tidak ada perubahan. Sebagian anggota kelompok usaha garam rakyat (KUGAR) yang mengajukan proposal untuk mendapatkan bantuan dana PUGAR, petani garam tersebut tidak bekerja sebagai petani garam dan juga tidak memiliki lahan garam.

\section{KESIMPULAN DAN SARAN}

\section{Kesimpulan}

Perencanaan anggaran belanja bantuan sosial pada anggaran pendapatan dan belanja daerah di Kabupaten Bantul belum sepenuhnya mencerminkan sebuah perencanaan strategis, di mana dokumen perencanaan yang berupa Rencana Pembangunan Jangka Menengah Daerah (RPJMD) dan juga Rencana Kerja 
Pembangunan Daerah (RKPD) yang ada di Kabupaten Bantul tidak memuat secara jelas dan mendasar sebagai dokumen perencanaan belanja bantuan sosial. Perencanaan belanja bantuan sosial di Kabupaten Bantul juga belum menunjukkan sebuah perencanaan kinerja untuk melaksanakan anggaran berbasis kinerja (performance based budgeting) hal ini ditunjukkan dengan tidak digunakannya beberapa tolok ukur anggaran berbasis kinerja seperti SPM, ASB, Standar Satuan Harga dan juga Indikator Kinerja di dalam proses perencanaan dan penganggaran belanja bantuan sosial.

\section{Saran}

Perlu adanya sinkronisasi antara Peraturan Menteri tentang Perencanaan Pembangunan Nasional, Pendoman Pengelolaan Keuangan dan juga Peraturan Menteri terkait belanja bantuan sosial, dengan kata lain perlu adanya revisi terhadap Peraturan Menteri Dalam Negeri berkaitan dengan Belanja Bantuan Sosial yang berasal dari APBD, dimana keberadaan penganggaran belanja bantuan sosial haruslah berkaitan langsung dengan program dan kegiatan yang menjadi penjabaran visi dan misi pemerintah daerah, sehingga mewujudkan satu kesatuan mulai perencanaan sampai penganggaran dan jelas program kegiatannya, sasaran dan target capaian kinerja dari input yang diberikan.

\section{UCAPAN TERIMA KASIH}

Ucapan terimakasih saya sampaikan kepada jajaran pimpinan dan staf yang ada di Dinas Kelautan dan Perikanan Kabupaten Sumenep dan Petani Garam Rakyat di Kabupaten Sumenep serta semua pihak yang telah mendukung selesainya penelitian ini.

\section{DAFTAR PUSTAKA}

[1]. Suhadak, dan Trilaksono Nugroho, (2007). Paradigma Pengelolaan
Keuangan Daerah dalam Penyusunan APBD di Era Otonomi. Malang, Bayu Media Publishing.

[2]. Mardiasmo, (2004). Otonomi dan Manajemen Keuangan Daerah, Yogyakarta, Penerbit Andi.

[3]. Bastian, Indra (2006). Sistem Perencanaan dan Penganggaran Pemerintah Daerah di Indonesia. Jakarta, Salemba Empat

[4]. Anggarini, Yunita dan Hendro Puranto ((2010). Anggaran Berbasis Kinerja Penyusunan Anggaran Secara Komprehensif. Yogyakarta, UPP STIM YKPN

[5]. Bryson, John M (2005). Perencanaan Strategis Bagi Organisasi Sosial Diterjemahkan oleh M. Miftahuddin. Yogyakarta, Pustaka Pelajar

[6]. Andayani, Wuryan (2007). Akuntansi Sektor Publik. Malang, Bayumedia Publising.

[7]. Ritonga, Irwan Taufik (2009). Perencanaan dan Penganggaran Keuangan Daerah di Indonesia, Yogyakarta, Sekolah Pasca Sarjana UGM.

[8]. Suara Merdeka, (2013), BPK diminta Audit Penerima Bansos. [internet] diakses melalui http://www.suaramerdeka.com/v1/in dex.php/read/cetak /2013/10/ 29/241434/BPK-Diminta-AuditPenerima-Bansos- Rabu, 30 Oktober 2013 Pukul 20.00 WIB.

[9]. Miles, Matthew B dan A Michael Huberman. (1992). Analisis Data Kualitatif. Diterjemahkan oleh Tjejep Rohendi Rohidi. Jakarta, Penerbit Universitas Indonesia (UI-Press).

[10]. Riyadi, Bratakusumah dan Deddy Supriady (2004). Perencanaan Pembangunan Daerah: Strategi Menggali Potensi Dalam Mewujudkan Otonomi Daerah. Jakarta, PT. Gramedia Pustaka Utama

[11]. Nurcholis, Hanif (2009). Perencanaan Partisipatif Pemerintah 
Daerah. Jakarta. Gramedia Widiasarana Indonesia

[12]. Kuncoro, Mudrajat (2011). Perencanaan Daerah : Bagaimana Membangun Ekonomi Lokal, Kota dan Kawasan. Jakarta, Salemba Empat.

[13]. Tjokroamidjojo, Bintoro. (1995). Pengantar Adminstrasi

Pembangunan. Jakarta, PT. Pustaka LP3ES Indonesia.

[14]. Arsyad, Lincolin (1999). Ekonomi Pembangunan. Yogyakarta, Bagian Penerbitan Sekolah Tinggi Ilmu Ekonomi YKPN.

[15]. Abe, Alexander (2005). Perencanaan Daerah Partisipatif. Yogyakarta, Pembaruan.

[16]. Mardiasmo, (2009). Akuntansi Sektor Publik. Yogyakarta, Penerbit Andi.

[17]. Wijayanti, Anita Wahyu (2012). Perencanaan Anggaran Berbasis Kinerja di Kabupaten Pasuruan. Tesis Magister Administrasi Publik, Program Pascasarjana Universitas Brawijaya, Malang.

[18]. Halim, Abdul dan Theresia Woro Damayanti (2007), Pengelolaan Keuangan Daerah. Yogyakarta UPP STIM YKPN.

[19]. Bastian, Indra (2010). Akuntansi Sektor Publik Suatu Pengantar. Jakarta, Penerbit Erlangga.

[20]. Nelson, Kenneth (2010). Social assistance and minimum income benefits in old and new EU democracies : International Journal of Sosial Welfare 2010:19: 367-378. USA, Journal compilation (C) 2009 Blackwell Publishing Ltd and the International Journal of Social Welfare [Internet] Diakses melalui: http://people.su.se/ kennethn/IJSW.p df, Jumat 2 Agustus 2013 jam 21.30 WIB.

[21]. Ritonga, Irwan Taufik dan Mansur Iskandar Alam (2010), Apakah Incumbent Memanfaat Anggaran Pendapatan dan Belanja
Daerah (APBD) untuk Mencalonkan Kembali Dalam Pemilihan Umum Kepala Daerah (Pemilukada) disampaikan dalam Simpusium Nasional Akuntansi XIII Purwokerto 2010.

[22]. Park, Nowook and Jae-Young Choi (2013). Making Performance Budgeting Reform Work A Case Study of Korea. World Bank Institute Vice Presidency Leadership and Governance Unit [internet]. Diakses dari http://wwwwds.worldbank.org/external/default/ WDS

ContentServer/IW3P/IB/2013/02/05/ 00015834920130205102606/Render ed/PDF/wps6353.pdf, Jumat, 21 Juni 2013 Jam. 20.00 WIB

[23]. Laporan Akhir Pemberdayaan Usaha Garam Rakyat tahun 2011, 2012 dan 2013 Dinas Kelautan dan Perikanan Kabupaten Sumenep 